\title{
TOWARDS GUIDELINES FOR DEVELOPMENT AND MANAGEMENT OF TRANSNATIONAL INFORMATION SYSTEMS
}

\author{
Angèle Cavaye ${ }^{1}$, Paul Mantelaers ${ }^{2}$, Wander van de Berg ${ }^{3}$, Arre Zuurmond ${ }^{4}$ \\ 'Dept of Information Systems, \\ University of Southern Queensland, Toowoomba, Australia \\ ${ }^{2}$ Dept of Computer Science, \\ Delft Technical University, Delft, the Netherlands \\ ${ }^{3}$ Dept of Systems Engineering, \\ Delft Technical University, Delft, the Netherlands \\ ${ }^{4}$ Dept of Public Administration. \\ Erasmus University, Rotterdam, the Netherlands
}

\begin{abstract}
This paper focuses on transnational information systems (TIS) that cross organisational as well as international boundaries. Such systems are being built and used in increasing numbers, but very little attention has been paid to TIS in the literature. This paper describes an empirical study which gathered case study data from four TIS projects. The data were used to describe problems encountered during TIS development and management and to discuss solutions found for those problems. An interesting finding was that organisations tend to address difficulties by lowering the level of aspiration of the TIS rather than addressing difficulties head-on.
\end{abstract}

Keywords: transnational information systems, IS development, IS management

\section{TRANSNATIONAL INFORMATION SYSTEMS}

There is an increasing use of and demand for information systems that transcend national boundaries transnational information systems (TIS). On the one hand developments in information and communication technology now make it possible to support many processes and tasks that cross company and national boundaries. On the other hand economic and political developments create demand for transnational information systems. This demand is clearly evident within the European Union in the context of a European market for persons, goods, capital and services. Similar developments can be seen on a global scale due to increased internationalisation. Examples of TIS include international payments systems, systems linking public administration agencies, international traffic control, and logistics systems linking different countries.

Development and management of TIS is not straightforward. The interorganisational and international nature of these systems introduces various difficulties and problems. One major reason for this may be that the participants are independent in most aspects and autonomous with regard to their own proprietary information systems. Another potential cause of difficulties is the international context which introduces cultural, legal and language difficulties among participants.

Most individual TIS to date are being developed on an ad hoc basis. Practical experience and empirical research show that many problems and solutions at first glance appear to be specific to a particular development effort, but often they are not unique at all. As the needs and opportunities for TIS become more prevalent, the call for generalised knowledge and guidelines to develop and manage TIS increases. Organisations want to know how to avoid difficulties and, if problems should occur, how to address them. Instead of continuing ad hoc development there is a need for structured do's and don'ts to aid organisations that may consider using, developing, managing, or otherwise participating in TIS.

A search through the literature revealed a lack of studies addressing the combined transorganisational and transnational IS setting. There is, however, a stream of literature concerning information systems linking parts of multinationals located in different countries. Several books on this subject have appeared containing articles highlighting the main drawbacks and difficulties when developing systems that cross national boundaries (Deans and Kane, 1992; Palvia and Palvia, 1994). Previous work on information systems for multi-nationals highlights issues concerning any systems that cross national boundaries: problems with language, different cultures, different abilities in terms of IT, differing sophistication of IT infrastructure and telecommunications, and legal differences.

Apart from research about global systems there is also a substantial body of writing about information systems crossing company boundaries. Much of the early discussion about interorganisational systems (IOS) focused on competitive benefits of developing IOS (Porter and Millar, 1985) and on facilitating and inhibiting factors in the development process (Reich and Benbasat, 1990). More recently research has taken on a more thoughtful note, pointing out that not all IOS provide benefits to all participants (Webster, 1995), that IOS may involve risks and conflict (Kumar and van Dissel, 1996), and that IOS involve management of relationships among the participants 
(Meier, 1995). Previous research suggests that major difficulties concerning systems crossing organisational boundaries include problems of responsibility, co-ordination, sharing of costs and benefits, and concems about competitive position.

This paper describes a study which attempted to take some early steps towards guidelines for the development and management of TIS. In view of the fact that very little existing research is available about TIS, this study focused on gathering information from an empirical setting as a basis for theory building. The paper proceeds as follows. First, the preparation of the empirical study is described. Then, four cases are introduced. Main TIS issues are summarised and then discussed.

\section{TIS RESEARCH ISSUES}

TTS difficulties and solutions to those difficulties can be categorised in a number of ways. This study used three dimensions for highlighting and distinguishing TIS issues.

One way of studying TIS issues is to distinguish issues in the informational, organisational and institutional domains. Parsons (1960) first discussed these distinct but complementary areas of responsibility and control; he argues that they are three quite separate domains within an organisation. We adopted this concept to categorise difficulties and potential solutions during the process of development and management of TIS. Parsons used the term 'technical domain' to denote the technical sub-organisation; we changed the term to 'informational domain' to underline the fact that this area of attention concerns data, procedures and people as well as the technical aspects of hardware, software and communications. Organisational issues refer to the way in which individual organisations need to adapt organisational structures, processes, regulations, skills, standards and ways of working to conform to the TIS. Institutional issues concern policy identification, political or competitive power struggles, role models as well as the formulation and development of decision making arrangements among participating organisations in order to ensure that the new order is accepted, adhered to and continues to operate effectively.

A second dimension for studying TIS issues concerns the various phases of the systems development process from identification of the need for a TIS through to the management of an operational TIS. Various authors provide different names for separate development phases, divide the system development process into different numbers of phases, and describe the development process with or without iteration and feedback loops. However, authors generally agree that (1) the need for a system should be identified and requirements have to be drawn up; (2) logical and physical design and building of the system has to take place; (3) the system has to be implemented; (4) the operational system has to be managed, updated and adapted over time. We used these four distinct phases to categorise difficulties according to stages of TIS development.

A third way of looking at the TIS area is to determine whether TIS issues lie in the interorganisational domain or the international one. Previous literature in global systems and in interorganisational systems presents many issues which are relevant to either the international domain or the interorganisational one. Our main concern was not merely to list those issues once again, but to derive from empirical research which type of issues are most dominant. We felt it was important to determine whether TTS difficulties are caused primarily by the international nature of the system or by the fact that TTS requires co-operation among and co-ordination of multiple autonomous organisations. Would the same or similar difficulties arise if the system were developed on a national basis? Is the international component a stumbling block?

\section{RESEARCH METHOD}

Although there is no literature specifically addressing transnational information systems, there is substantial practical experience with such systems. Within the public sector in the European Union alone about 30 transnational systems are currently operational or under development (Kroon, 1997). This experience and knowledge tends to remain with the organisations involved unless an attempt is made to collate and generalise the lessons learnt by individual organisations. For this reason it was decided to conduct an empirical study.

Case research was selected as the appropriate research method. Carrying out a number of case studies would provide rich data which is important in the process of theory building (Yin, 1994). Observation of phenomena and relationships in a variety of settings forms the basis for conceptualisation and generalisation. Hence, studying the development processes of existing TTS, being guided by existing constructs, keeping an open mind to uncovering new relationships, and subsequently conceptualising from findings is a sound method for formulating guidelines for TIS development and management.

Selection of cases for this exploratory study was based on several criteria. Cases had to concern TIS but had to be sufficiently dissimilar to provide a rich picture of the problem area. Hence, cases were selected from different sectors. TIS in the cases had to support a primary process in the organisations and cases had to involve systems which were operational even if only in an early version. At least one TIS was sought which involved a non- 
automated system; this allowed the researchers to ascertain whether TIS development difficulties are related purely to technology or not. Cases need not be highly successful; in fact we preferred to have cases which had encountered or were facing difficulties. An additional criterion was the requirement that organisations had to be willing and able to participate in the study.

A multi-disciplinary research team was put together consisting of experienced researchers from Computer Science, Information Systems, and Management. A list of definitions, a case protocol and a framework for writing up individual cases was agreed upon. Researchers went into the field studying 4 TIS cases by collecting documentation, tracing TIS development over time, interviewing informants who were or are involved with the TIS, obtaining information from IT informants and also from informants primarily concerned with the business processes supported by the TIS.

The findings reported here are the result of this exploratory study.

\section{THE FOUR CASES}

Four cases were studied: EUCARIS, TRANSIT, GEIS and TAPS. EUCARIS is a TIS that enables personnel in different countries to have access to other national car and driving licence registration systems; the primary aim of EUCARIS is to lower the number of stolen cars being registered in another country as a legal vehicle. TRANSIT is the TIS that is being developed to speed up and facilitate custom administration concerning goods that are imported into the European Union and to which a suspense regime is applied; TRANSIT should also lead to more effective fraud detection and prevention. GEIS is the case concerning the collection and aggregation of international greenhouse gas emissions; the aim of the system is to monitor individual country's emissions which should help to stabilise emission levels. TAPS is the acronym for Transnational Ambulatory Payment Systems. This is an embedded case where four different systems were studied; each system enables private customers to make non-cash payments internationally. The aim of the system is to facilitate transborder payment processing.

\section{- EUCARIS}

The incidence of car theft has increased alarmingly during the past 10 years. Often stolen cars are taken across European borders to be re-registered (and thus white-washed) in another country. Registration authorities are obliged to register a car unless they can be prove within a short period of time that the car is registered elsewhere and therefore is a stolen car. When in doubt about the legality of a car that is being offered for registration, authorities traditionally write, phone or fax to foreign registration authorities. This process is inadequate, as it is time-consuming and difficult to manage.

Computerised access to registration databases in other countries would facilitate the process of checking for legal registrations. It would be much faster, more accurate, and more likely to combat re-registration of stolen cars. The Dutch car registration authority conceived the idea for building a TIS to enable instantaneous, electronic searching and checking of car registration data across Europe; the system was called EUCARIS (European Car Registration Information System).

Very early on it became clear that it would not be possible nor necessary to integrate the registration systems of various countries into one large system. There is at present no single European car numbering system to identify individual cars Europe-wide. Also, current registration systems each use different data definitions, which complicates the possible development of a single system. In addition, individual registration authorities value their autonomy and a central registration system would threaten that autonomy. Hence, it was decided to develop a relatively simple system: a common shell to provide a query interface to the separate systems of participating countries.

EUCARIS has been operational since 1995. Currently six countries are on-line (the Netherlands, Belgium, Luxembourg, UK, Hungary and Poland); 14 other countries are preparing to go on-line; another 10 have enquired about participation.

\section{- TRANSIT}

Goods that are brought into the European Union (EU) are subject to taxes and duties. Since payment is not necessarily required at the point of entry, European customs officials have to keep track of goods moving within Europe and, in particular, have to be able to trace what duties and how much taxes have been paid.

Building a TIS to computerise this international customs process was first considered in the early 1980s. A properly working TIS would facilitate tracking and tracing of goods; it would enable immediate comparison of goods and duties paid, speeding up the clearance process; it would produce readable, accurate and up-to-date information at any customs office. The private sector would also benefit because of faster clearance procedures. Disagreements among different EU partners withheld a TIS from moving beyond the 'nice idea' phase. 
The current project to build a TIS, called TRANSIT, is the third attempt at developing computerised procedures. This time a serious effort has been put into TIS development: fraud problems have reached alarming proportions with fraud concerning goods in transit within the EU adding up to billions of US $\$$. Computerisation of the transit procedures has now been placed high on the list of priorities of the EU.

EDI messages have been designed and national gateways are being set up. In order to account for diversity in local systems and to respect autonomy of individual customs agencies no attempt has been made to integrate the various systems. Instead, for each country one customs application host is built which connects the central TIS system with local systems in various countries. In this way local systems and procedures need not be adapted to a single European-wide system; similarly, the diversity in local systems and procedures needs not affect the central TIS. At the end of 1996 the TRANSIT project is in its pilot phase; customs authorities aim to have the system fully operational as soon as possible.

\section{- GEIS}

The global community has become increasingly concerned with the emission of dangerous gases into the atmosphere and the effect of those gases on the environment. It is generally recognised that combating dangerous emissions should not be a unilateral effort from individual countries. Sustainable reduction in emissions can only be achieved by commitment from and co-operation among countries. In the early 1990s both the EU and the world community at large (through the United Nations) agreed to address the rise in greenhouse emissions.

Information is a vital ingredient in any effort to combat dangerous (greenhouse gas) emissions: information is required about the state of climatic change in different countries, about technologies to combat dangerous emissions, and about projects to counter the amount of and effects of dangerous emissions. This information has to be passed from individual countries to transnational organisations which collate and monitor the data.

A separate organisation (within the UN) has been set up to deal with information about emissions and climatic change. The system for international information exchange is non-computerised, but involves detailed agreements about the exact data to be passed on to the transnational organisation. Guidelines have been written and accepted as the standard procedures and rules according to which each nation will collect and present international greenhouse gas information. Not all countries are able to collect detailed information; hence, in the cases of developing countries standard procedures are simplified. Even among western countries it is difficult to ensure that all countries adhere to standard reporting rules; monitoring is therefore an important function of the transnational organisation managing the system.

\section{- TAPS}

Banks have had to agree on a transnational system to process and complete payments made in one country by a customer holding accounts in another country. Customers travel across borders and wish to obtain cash or to pay for products in foreign countries by debiting their account in the home country. Such payments made by individuals in other countries are called ambulatory payments. In Europe there are currently four systems in place to support ambulatory payments.

The oldest system, introduced in the 1970 s, is the Eurocheque - an internationally recognised cheque where the customer has to enter not only the amount payable, but also the appropriate denomination for payment. The second payment system is the internationally usable Europass - a magnetic strip card requiring PIN identification at all times. The third system is the Eurocard creditcard which requires signature and PIN for identification. The fourth system has been introduced in 1996: a chipcard with magnetic strip. The plan is to phase out the earlier systems and concentrate on the more modem card-based systems.

These four systems, although distinct, are processed in the same way by banks. Individual countries have a single channel for international transactions so that all foreign currency processing is centralised. The organisation operating the central channel maintains links to the European-wide organisation Europay which operates transnational card and Eurocheque transactions. Europay performs international clearing and links with national clearing houses in different countries.

\section{MAIN TIS ISSUES}

The cases were compared along the three basic dimensions mentioned earlier: the informational, organisational and institutional domains; issues according various phases of development; issues categorised according to the interorganisational and international domain. Findings of the cross case comparison are summarised below. 


\section{Issues according to the informational/organisational/institutional domains}

Table 1 presents a summary of the problems faced by the four TIS categorised according to the informational, organisational and institutional nature of the problem. The table also shows which cases encountered which difficulties. The summary in Table 1 shows that development and management of TIS concerns difficulties in all three categories of problems: there are informational as well as organisational and institutional problems. Some of the problems are clearly created by and because of the TIS; other problems exist regardless of the TIS.

Table 1 - Informational, organisational and institutional TIS problems

\begin{tabular}{|c|c|c|c|c|c|}
\hline Category & Problem & EUCARIS & TRANSIT & GEIS & TAPS \\
\hline \multirow[t]{5}{*}{$\begin{array}{l}\text { Infor- } \\
\text { mational }\end{array}$} & Technological limitations to development & & $\mathrm{X}$ & & $\begin{array}{c}\mathrm{X} \\
\text { (Eurocheque) }\end{array}$ \\
\hline & $\begin{array}{l}\text { Insufficient local sophistication in terms } \\
\text { of ability to collect data }\end{array}$ & & & $\mathbf{X}$ & \\
\hline & $\begin{array}{l}\text { Insufficient local sophistication in terms } \\
\text { of IT infrastructure or applications }\end{array}$ & & $\mathrm{X}$ & $\bar{X}$ & $\mathrm{X}$ (creditcard) \\
\hline & $\begin{array}{l}\text { Technical complexity of integrated } \\
\text { system }\end{array}$ & & $\mathrm{X}$ & & $\mathrm{X}$ (chipcard) \\
\hline & Diversity of systems to be connected & $\mathbf{X}$ & $\mathrm{X}$ & $\mathbf{X}$ & $\mathrm{X}$ (3 systems) \\
\hline \multirow{3}{*}{$\begin{array}{l}\text { Organi- } \\
\text { sational }\end{array}$} & Unequal sharing of costs and benefits & & $\mathrm{X}$ & & \\
\hline & Lack of a transnational organisation & $\mathbf{X}$ & & & \\
\hline & $\begin{array}{l}\text { Lack of transnational organisation to } \\
\text { manage TIS }\end{array}$ & & & $\bar{X}$ & \\
\hline \multirow[t]{6}{*}{$\begin{array}{l}\text { Institu- } \\
\text { tional }\end{array}$} & $\begin{array}{l}\text { Problem to be addressed by TIS is seen } \\
\text { as low priority by (some) individual } \\
\text { participants }\end{array}$ & & $\mathrm{X}$ & $\mathrm{X}$ & $\begin{array}{l}\mathrm{X} \text { (credit and } \\
\text { chipcard) }\end{array}$ \\
\hline & $\begin{array}{l}\text { Disagreement among various local } \\
\text { organisations about responsibility for } \\
\text { information (local power issue) }\end{array}$ & $\mathrm{X}$ & & $\mathrm{X}$ & \\
\hline & $\begin{array}{l}\text { Lack of consensus about degree of } \\
\text { centralisation }\end{array}$ & & $\mathrm{X}$ & & $\mathrm{X}$ (3 systems) \\
\hline & Fear for loss of autonomy & $\mathbf{X}$ & & $\mathbf{X}$ & \\
\hline & $\begin{array}{l}\text { Legal procedures in various countries } \\
\text { concerning data and privacy }\end{array}$ & $\mathrm{X}$ & & & $\mathrm{X}$ (chipcard) \\
\hline & $\begin{array}{l}\text { Cultural/language differences between } \\
\text { countries }\end{array}$ & & $\mathrm{X}$ & $\mathbf{X}$ & $\begin{array}{l}X \text { (magnetic } \\
\text { and } \\
\text { creditcard) }\end{array}$ \\
\hline
\end{tabular}

Informational issues need not be permanent bottlenecks. Difficulties like lack of sophistication in data collection abilities or lack of IT infrastructure tend to be dissolved over time as individual organisations or countries develop their systems. Similarly, technological limitations tend to be overcome as time passes and new developments become commercially available. Diversity of systems among partners is also overcome by increasing standardisation of products. Although technical and informational problems are real and occurred in three of the cases, they are not necessarily long-term difficulties. It should be noted that solutions for informational problems are not necessarily informational but can also be organisational or institutional. Similarly, organisational and institutional problems can be addressed by technical solutions.

Organisational issues, like inequality in costs and benefits of TIS and the lack of transnational bodies to develop and manage TIS, are co-ordination and co-operation issues. Co-operation of individual organisations is necessary for the concept of a meaningful TIS to evolve and co-ordination is necessary for the development and management of the actual TIS itself. In order to gain co-operation of individual organisations it is important to ensure benefits are shared or, at least, costs are borne by those that stand to gain most of the TIS. The absence of transnational organisations inhibits fast or easy TIS development; a transnational body is particularly valuable for co-ordinating day-to-day TIS affairs.

Institutional problems tend to be present but latent prior to TIS development; they often come to the fore during 
early discussions about development and management of the TIS. Such problems are not necessarily directly concerned with the TIS itself and may affect TIS indirectly. Clearly, existing institutional problems have to be addressed if the TIS is to be successful. An example of an existing problem that affects TIS indirectly is 'disagreement among various local organisations'. (Potential) participants of the TIS can have disagreements about data, technical matters or policy with parties outside the TIS and such disagreements can affect the ability of the participants to participate fully. Political struggles or business competition between TIS participants or with outsiders are important determining factors for the success of the TIS. A system that is sound from a technical point of view may turn out to be not feasible due to institutional issues.

Table 2 - Issues during system life cycle phases

\begin{tabular}{|c|c|c|}
\hline Life cycle phase & Problems & Solutions \\
\hline \multirow[t]{5}{*}{ Identification } & $\begin{array}{l}\text { Need for a TIS identified, but not } \\
\text { possible to translate into TIS } \\
\text { (TRANSIT first and second } \\
\text { attempt) }\end{array}$ & $\begin{array}{l}\text { delay plans for development } \\
\text { indefinitely }\end{array}$ \\
\hline & $\begin{array}{l}\text { Possible TIS identified but too } \\
\text { many organisational problems to } \\
\text { begin actual development } \\
\text { (TRANSIT second attempt) }\end{array}$ & delay indefinitely \\
\hline & $\begin{array}{l}\text { Need for TIS acknowledged, but } \\
\text { fear for loss of autonomy } \\
\text { (EUCARIS) }\end{array}$ & $\begin{array}{l}\text { opt for technical solution that is } \\
\text { highly decentralised }\end{array}$ \\
\hline & $\begin{array}{l}\text { Need for TIS acknowledged, but } \\
\text { not seen as high priority } \\
\text { (TRANSIT; GEIS) }\end{array}$ & $\begin{array}{l}\text { - delay indefinitely (TRANSIT); } \\
\text { - translate common need for TIS } \\
\text { into local issue for participant } \\
\text { (GEIS) }\end{array}$ \\
\hline & $\begin{array}{l}\text { TIS will lead to uneven sharing of } \\
\text { costs and benefits (TRANSIT) }\end{array}$ & $\begin{array}{l}\text { (political) pressure to accept } \\
\text { anyway }\end{array}$ \\
\hline \multirow[t]{3}{*}{ Designing and building } & $\begin{array}{l}\text { TIS is turning into a technically } \\
\text { complex system (TRANSIT) }\end{array}$ & $\begin{array}{l}\text { - superior project management } \\
\text { - discussion with various parties } \\
\text { - participate development }\end{array}$ \\
\hline & $\begin{array}{l}\text { Diversity of systems that need to be } \\
\text { linked (EUCARIS, TAPS) }\end{array}$ & $\begin{array}{l}\text { - opt for common interface and } \\
\text { local gateway configuration } \\
\text { - experimental development method } \\
\text { - iterative development }\end{array}$ \\
\hline & $\begin{array}{l}\text { Time/manpower for TIS } \\
\text { development difficult to find among } \\
\text { participants (EUCARIS) }\end{array}$ & outsourcing of development \\
\hline Implementation & $\begin{array}{l}\text { Different abilities of participants (in } \\
\text { terms of IT) do not allow } \\
\text { implementation of full system } \\
\text { (GEIS, TRANSIT) }\end{array}$ & $\begin{array}{l}\text { - different entry levels (GEIS) } \\
\text { - phased implementation (GEIS, } \\
\text { TRANSIT) }\end{array}$ \\
\hline \multirow[t]{4}{*}{$\begin{array}{l}\text { Ongoing management and } \\
\text { maintenance }\end{array}$} & $\begin{array}{l}\text { Difficulty of ensuring that standards } \\
\text { are enforced and TIS is used } \\
\text { properly (EUCARIS, GEIS) }\end{array}$ & $\begin{array}{l}\text { - third party management of TIS } \\
\text { itself; } \\
\text { - monitoring committee from TIS } \\
\text { general management body (GEIS) }\end{array}$ \\
\hline & $\begin{array}{l}\text { Time/manpower for co-ordination } \\
\text { (EUCARIS) }\end{array}$ & $\begin{array}{l}\text { outsourcing of day-to-day } \\
\text { management of TSS }\end{array}$ \\
\hline & $\begin{array}{l}\text { Long term integration into existing } \\
\text { systems is necessary for long-term } \\
\text { success of TIS (EUCARIS, TAPS) }\end{array}$ & $\begin{array}{l}\text { institutionalisation of new } \\
\text { processes by local organisations is } \\
\text { required }\end{array}$ \\
\hline & $\begin{array}{l}\text { Expanding the system to include } \\
\text { more tasks/actors (EUCARIS, } \\
\text { TAPS) }\end{array}$ & $\begin{array}{l}\text { - discussion, } \\
\text { - prototyping } \\
\text { - consensus building } \\
\end{array}$ \\
\hline
\end{tabular}




\section{Issues during the various phases of the system development}

Every system moves through a number of recognisable phases during the development process; each of the phases may cause and may have to address different problems. The problems (and the solutions) that were found in the four cases are summarised in Table 2 according to the various system life cycle phases.

System identification. Difficulties in the identification phase appear to be inversely related to the apparent urgency of the problem that is to be addressed by the TIS. When the issue is considered important and urgent, identification of and agreement about the concept of a TIS is relatively easily reached. However, when the problem that TIS addresses is not considered a high priority, difficulties seem to mount up and the TIS does not get beyond the 'nice idea' phase.

Designing and building of the TIS. Difficulties at this phase of development are primarily technical in nature. The technical issues are made more complicated because of the great number of participants and their different objectives. The difficulties are addressed by finding a technical solution or by improved organisation of the development process. Although the problems in this development phase might seem difficult, finding solutions to the problems did not seem a major issue in any of the cases.

Implementation. When the TIS has been properly identified and has been agreed upon by participants, implementation is a feasible matter, although likely to be laborious and costly. In both the TRANSIT and the GEIS case there is large diversity among the participants when it comes to informational and technical sophistication and facilities. This clearly inhibits implementation of the full TIS.

Management and on-going maintenance. Management issues include ensuring that participants see to their local systems so that they interface correctly with the TIS, enforcing standards and continuing use of the TIS, developing new functionality and increasing the scope of the TIS. EUCARIS, for example, is a TIS that has reached this phase and faces the new challenge of keeping the earlier momentum going. For the TAPS case this implies further integration inside each bank and at the national and transnational operational body level.

Table 3 - Interorganisational vs. international issues

\begin{tabular}{|l|c|c|}
\hline Problem & Interorganisational & International \\
\hline $\begin{array}{l}\text { Insufficient local sophistication in terms of } \\
\text { IT infrastructure or applications }\end{array}$ & $\mathrm{x}$ & \\
\hline Technical complexity of integrated system & $\mathrm{x}$ & \\
\hline Diversity of systems to be connected & $\mathrm{x}$ & \\
\hline Unequal sharing of costs and benefits & $\mathrm{x}$ & \\
\hline $\begin{array}{l}\text { Disagreement among various local } \\
\text { organisations about responsibility for } \\
\text { information (local power issue }\end{array}$ & $\mathrm{x}$ & $\mathrm{x}$ \\
\hline $\begin{array}{l}\text { Lack of consensus about degree of } \\
\text { centralisation }\end{array}$ & $\mathrm{x}$ & $\mathrm{x}$ \\
\hline Fear for loss of autonomy & $\mathrm{x}$ & $\mathrm{x}$ \\
\hline $\begin{array}{l}\text { Insufficient local sophistication in terms of } \\
\text { ability to collect data }\end{array}$ & $\mathrm{x}$ & $\mathrm{x}$ \\
\hline $\begin{array}{l}\text { Lack of a transnational organisation to } \\
\text { develop the TIS }\end{array}$ & & $\mathrm{x}$ \\
\hline $\begin{array}{l}\text { Lack of transnational organisation to } \\
\text { manage TIS }\end{array}$ & & \\
\hline $\begin{array}{l}\text { Legal procedures in various countries } \\
\text { concerning data and privacy }\end{array}$ & & \\
\hline $\begin{array}{l}\text { Cultural/language differences between } \\
\text { countries }\end{array}$ & & \\
\hline
\end{tabular}




\section{Issues derived from interorganisational or international setting}

Difficulties encountered during TIS development or management can be caused by the interorganisational nature of the TIS or by the international component of the TIS. Table 3 lists and categorises TIS problems from Tables 1 and 2 according to interorganisational or international causes.

International context. The usual difficulties of operating across national boundaries were evident in all cases. Although there are international differences and potential difficulties when collaborating internationally, many organisations and the people within them accept the differences and are willing to work towards overcoming such barriers. In the EUCARIS case where legal difficulties inhibited Germany from participating fully, the German car registration authority took steps to ensure the law was adjusted and the EUCARIS organisation accepted Germany as a partner that would join as soon as legally possible. In the TRANSIT case documents were translated into various languages to ensure that partners would all have access to documents in their own or in a very familiar language. In some cases there was no transnational organisation, but the need for and importance of such an organisation was recognised in all cases and an organisation for dealing with transnational issues was established. In all, the international context does present difficulties for TIS development and management, but those difficulties are recognised, can usually be overcome and are addressed directly.

Interorganisational context. The table above would suggest that there are many more problems due to the interorganisational context than to the international nature of TIS. Some of these are technical and systems issues which might be overcome fairly easy; other issues concern autonomy and responsibility of organisations and equality among organisations. Interorganisational information exchange requires common decisions, consensus and commitment. If individual organisations feel their autonomy is threatened or they are not gaining benefits on a par with other organisations, then they can withdraw participation or can become a difficult partner in the TIS. In each of the cases difficulties of this kind were found and each of these problems proved to be difficult to address.

\section{TIS issues which emerged during the study}

Apart from issues which we had anticipated and had specifically looked for in the cases, issues emerged during the course of the study as empirical evidence was collated.

A major issue which emerged was the level of aspiration of the TIS. Under rational norms we would expect organisations to aim at maximising the opportunity offered by a TIS, building a system to optimise efficiency and shared benefits. In practice, though, successful TIS organisations show satisficing behaviour: adopting a TIS which is acceptable or 'good enough'. TIS development involves difficulties and TIS participants address difficulties during the development stages by lowering the level of aspiration of the TIS, be it in time constraints, in functionality, or in the cost/benefit ratio.

From a systems development perspective, an 'optimum' TIS requires high levels of co-operation among partners and involves consensus on many aspects of the system. In the context of co-operation among independent partners it is not always feasible nor desirable to achieve high levels of consensus and commitment. There are many potential disagreements and mismatches which may mean that the 'optimum' TIS is never built and that a TIS at a lower level of aspiration is developed and implemented instead.

Participants may have agreed to a diminished level of aspiration for the TIS, but the initial problems tend to resurface at a later stage. Once the 'simplified' system is operational, attempts are made to improve and enhance the system by adding functionality, adding further partners, increasing the scope of the TIS (e.g. in the case of EUCARIS). At that moment the problems which led to a reduced level of aspiration in the first place can surface again. It would seem that reducing the level of aspiration at early stages of development may postpone the moment of facing difficulties with the TIS, but it does not eliminate the problems. But facing the problems headon early in development may well lead to the failure, or at least serious delay, of the TIS.

Two other issues need to be mentioned here. We classified TIS issues into three domains: the informational, the organisational, and the institutional domain. Both problems and solutions regarding TIS can be classified that way, but problems in one domain are not necessarily solved by solutions from the same domain. Often technical solutions are used to address organisational and institutional problems. The second issue concerns the making of trade-offs. Development and management of TIS requires the wisdom to make the right trade-off between desirability and feasibility of solutions. In each case participants had to try and find the right balance between technical possibilities, costs, organisational competencies, power, etc.

This study was exploratory in nature and the results reported here are preliminary. Further research could study other cases and could investigate TIS cases in settings outside the European Union. Research could also involve 
investigators in different countries to study individual TIS from a multiple country perspective. Compiling and combining findings from multiple studies should enable us to formulate guidelines and concepts to aid TIS development and management.

\section{REFERENCES}

Deans, P. C. and M.J. Kane (1992) International dimensions of information systems and technology, PWS, Kent

Kroon, N. (1997) “Europese informatiesystemen: grensverleggend?" PhD-thesis, Erasmus University Rotterdam (in Dutch), forthcoming

Kumar, K. and H. van Dissel (1996) "Sustainable collaboration: managing conflict and co-operation in interorganisational systems", MIS Quarterly, Sept, 20(3), pp279-300

Martin, J. (1989) Information Engineering, Book I: Introduction, Prentice Hall, Englewood Cliffs, New Jersey

Meier, J. (1995) "The importance of relationship management in establishing successful interorganisational systems", Journal of Strategic Information Systems, 4(2), pp135-148

Miles, M. B. and A.M. Huberman (1984) Analysing qualitative data: a source book for new methods, Sage Publications, Beverly Hills

Palvia, S. And P. Palvia (1994) Global issues of information technology management, Idea Group Publishing, Harrisburg

Parsons, T. (1960) Structure and process in modern societies, Free Press of Glencoe, New York

Porter, M. and V.E. Millar (1985) "How information gives you competitive advantage", Harvard Business Review, July-August, pp149-160.

Reich, B. H. and L. Benbasat (1990) "An empirical investigation of factors influencing the success of customer oriented information systems", Information Systems Research, 1(3), pp325-347

Webster, J. (1995) "Networks of collaboration or conflict? Electronic Data Interchange and power in the supply chain", Journal of Strategic Information Systems, 4(1), pp31-43

Yin, R. K. (1994) Case study research: design and method, 2nd edition, Sage Publications, Londo 